\title{
Survival Analysis in Breast Cancer Patients: Frailty Models
}

\section{Meme Kanserli Hastalarda Yaşam Analizi: Frailty Modeli}

\author{
İsa Dede ${ }^{1}$, Şirin Çetin ${ }^{2}$ \\ ${ }^{1}$ Antakya Devlet Hastanesi, Tıbbi Onkoloji Kliniği, Antakya \\ ${ }^{2}$ Ondokuz Mayıs Üniversitesi, Samsun
}

Dergiye Ulaşma Tarihi: 26.09.2016 Dergiye Kabul Tarihi:24.07.2017 Doi: 10.5505/aot.2017.54254

\begin{abstract}
ÖZET
GİRIŞ ve AMAÇ: Meme kanseri hastalarına ait heterojen yaşam verilerinin modellenmesi ve sağkalım süresini etkileyen faktörlerin belirlenmesi.

YÖNTEM ve GEREÇLER: 181 meme kanseri hastasından retrospektif olarak elde edilen yaşam verilerinin zayıflık modeli ile analizi yapıldı.

BULGULAR: Analize alınan 181 meme kanserli hastanın ortanca genel sağkalımı 74 ay (\%95 güven aralığı; 61.88-86.78) olarak bulundu. Tümör boyutu, lenf nodu sayısı, hormon reseptörünün negatifliği başarısızlı̆ı etkileyen önemli bir faktör olarak bulundu $(\mathrm{p}<0.05)$. Ayrıca cerrahi işlem ile kemoterapi başlama tarihi arasındaki sürenin uzatılması yaşam süresini etkileyen bir faktör olarak bulundu $(\mathrm{p}=0.002)$. Herhangi bir meme kanseri hastasının belirlenen bir zamanda, tüm hastalar için belirlenen riskten yaklaşık 3 kat daha fazla risk taşıyabileceği bulundu $(\mathrm{p}<0.001)$.
\end{abstract}

TARTIŞMA ve SONUÇ: Yapılan analiz sonucunda meme kanseri hastalarının yaşam süresini etkileyen tümör boyutu, lenf nodu büyüklüğü, hormon reseptörünün negatifliği ve cerrahi müdahale ile kemoterapi başlama tarihi arasında geçen zamanın uzatılması gibi faktörlerin yanı sıra yaşam süresini etkileyen çevresel ya da genetik gizli faktörlerin olduğu söylenebilir. Bu gizli faktör ya da faktörlerin herhangi bir meme kanseri hastasında 3 kat daha fazla risk olasılığı taşıdığını ifade edebiliriz.

Anahtar Kelimeler: Meme Kanseri, Yaşam Analizi, Zayıflık Modeli

\begin{abstract}
INTRODUCTION: Modelling of heterogeneous survival data of breast cancer patients and the determination of the factors affecting the time of survival.

METHODS: Retrospectively obtained survival data of 181 breast cancer patients were analyzed by means of the model of frailty models.

RESULTS: The median of survival time of 181 breast cancer patients analyzed was determined as 74 months (95 $\%$ CI, 61.88 to 86.78). Size of the tumor, number of Iymph nodes and the negativity of hormone receptor ( $<<0.05$ ) were found as important factors influencing the failure. In addition, the time between the chemotherapy and surgical operations influence the failure directly $(\mathrm{p}=0.002)$. It is found that a breast cancer patient is under 3 times more risk than any other patients $(\mathrm{p}<0.001)$.

DISCUSSION AND CONCLUSION: The analysis findings have put forward that there may also be some latent genetic or environmental factors influencing the survival time of the breast cancer patients in addition to factors such as the size of the tumor, size of the lymph node, the negativity of hormone receptor and the time between the chemotherapy and surgical operations and these latent factors may increase the risk level three fold.

Keywords: Breast Cancer, Survival Analysis, Frailty Model

\section{Giriş}

Meme kanseri heterojen tipte bir kanser türüdür.

Meme kanseri kadınlarda kanser olgularının \%23'ünü ve kanser ölümlerinin \%14'ünü oluşturmaktadır (1). Literatürde meme kanserinin farklı tedavi seçeneklerine

yanıtlarını belirleyen çok sayıda özellik belirtilmiş ve tümör çapı, tümör grade'i, hasta yaş1, hormon reseptörlerinin durumu ve aksiler lenf nodlarının tutulması temel prognostik faktörler olarak saptanmıştır. Bu çalışmanın amacı meme kanserli hastaların yaşam süresini etkileyen prognostik faktörleri araştırmaktır.
\end{abstract}




\section{Gereç ve Yöntem}

Bu çalışmada Hatay Devlet Hastanesi'nin 181 meme kanseri hastasından retrospektif olarak alınan verilerin analizinde SPSS 21.0 ve Stata 14 demo sürümü kullanılmıştır (2). $\mathrm{Bu}$ çalışmada, hastalığın primer tedaviden sonra ilk nükse kadar geçen toplam süre "hastalıksız sağkalım süresi” olarak alındı. Hastalığın nüksetmesi "başarısızlık" olarak ifade edilmiş ve hastalığ "durdurulmuş" olarak tanımlandı. Hastaların başarısızlık veya durdurulmuş süreleri sağkalım süreleri (minimum 1 ay, maksimum 120 ay) olarak ifade edilmiştir. Çalışmada hastaların demografik özellikleri (çocuk sayısı, yaş, menopoz durumu, eğitim durumu, sigara öyküsü, tümör lokalizasyonu, tümör grade'i, tümör boyutu, metastatik lenf nodu sayıs1, hormon profili, C-ERB B2 durumu, tan1 konması ile tedavi başlangıcı arasında geçen süre, metastaz bölgeleri gibi parametrelerin sağkalım süreleri üzerine etkileri araştırıldı. Değerlendirmeler retrospektif olarak hastaların kanser tanı ve takip kartlarından yapıldı ve ortalama hastalıksız sağkalım süresi hesaplandı.

Hormon reseptörleri (östrojen reseptörü (ER) ve progesteron reseptörü (PR)) pozitifliği hastalıksız sağkalım ve genel sağkalım ile ilişkilidir. Önceleri biyokimyasal testler tercih edilirken günümüzde immunohistokimyasal testler kullanılmaktadır. ER pozitifliği; tümör hücrelerinin $\% 1$ veya daha fazlasının pozitif nükleer boyanma göstermesi olarak kabul edilir (3). Araştırmamızda tümör örnekleri her ikisinin negatif olması durumunda hormon reseptör (HR) negatif olarak değerlendirilirken, herhangi birinin pozitif olmas1 durumunda da HR pozitif olarak alınd.

C-ERB B2 (HER-2/NEU) onkogeni 185 Kda'l1k transmembran glukoproteini kodlar. Glukoproteinin intrasellüler tarafinda tirozin kinaz aktivitesi vardır. C-ERB B2 epidermal büyüme faktörü ailesindendir. $\mathrm{Bu}$ reseptörler epidermal ileti yolaklarını aktivasyonunda önemli bir role sahiptir. Epidermal yolaklar epitel hücresinin büyümesini ve diferansiyasyonunu kontrol eder. C-ERB B2 onkogeninin over ekspresyonu invaziv meme kanserlerinin yaklașı $\%$ \%30'unda mevcuttur. HER-2/NEU aktivitesinin ölçümü çeşitli metodlar ile yapılır. Fluoresan in situ hibridizasyon (FISH) metodu HER-2/NEU amplifikasyonunu tespit edebilir. HER-2/NEU RNA overekspresyonu ise Northern Blot veya reverse transkripsiyon polimeraz zincir reaksiyonu (RT-PCR) ile saptanabilir. Bunun yanında HER-2/NEU protein ürünleri Western Blot, enzime bağlı immunosorbent assay (ELISA) veya immunohistokimyasal (IHK) ile değerlendirilebilir (4). Bizim çalışmamızda İHK ve FISH yöntemi kullanıld. İHK ile skor 0 : membran boyanması yok, skor 1: tüm membranı çevreleyen \%10'dan az boyanma, skor 2: invaziv karsinom hücrelerinin en az $\% 10$ 'unda sitoplazmik membranı tümüyle çevreleyen orta şiddette boyanma veya \% 30'dan daha az kuvvetli boyanma, skor 3: en az $\%$ 30'unda sitoplazmik membranı çevreleyen kuvvetli boyanmadır. Skor 0 ve 1 İHK olarak negatiftir, in situ hibridizasyon gerekmez. Skor 2 İHK olarak şüpheli pozitiftir, in situ hibridizasyon önerilir. Skor 3 İHK olarak pozitiftir, in situ hibridizasyon önerilmez (5). TNM evrelemesi olarak American Joint Committee on Cancer (AJCC) 2010 evrelemesi kullanıldı. T1: tümör boyutu $2 \mathrm{~cm}$ 'den küçük, T2: tümör boyutu $2 \mathrm{~cm}$ ve $5 \mathrm{~cm}$ aras1, T3: tümör boyutu $5 \mathrm{~cm}$ 'den büyük, T4: tümör herhangi bir boyutta, göğüs duvarına invazyonu veya deri tutulumu olması olarak siniflandirildı. Çalışmamızda N1: aksillada 1-3 lenf nodu tutulumu, N2: 4-9 lenf nodu tutulumu, N3: 10 ve daha fazla lenf nodu tutulumu olarak siniflandirildı.

Çalışmaya aldığımız 181 hastanın 26 hasta evre 1,61 hasta evre 2, 69 hasta evre 3, 25 hasta da evre 4 hasta grubunda idi. Evre 1,2,3 olan hastalar adjuvan tedavi ile tedavi edildi. Evre 4 olan metastatik hastalar kemoterapi, hormonal tedavi ve semptomlarına göre palyatif radyoterapi ile tedavi edildi.

Çalışmamızdaki meme kanseri hastalarına ait yaşam verisinin analizinde modelleme sürecinin amac1, hazard fonksiyonunu etkileyen değişkenlerin sağkalım süresini nasıl etkilediğini belirlemek olduğundan veriyi analiz etmek için sağkalım analizinde en sik kullanilan model Cox regresyon olarak adlandırdığımız yarı parametrik modeli kullanmayı hedefledik. Ancak bu modeli kullanabilmek için orantılı hazard varsayımının, hazard oranının zamana karşı sabit olması varsayımını sağlaması gerekmektedir (6). Bu varsayımın sağlanıp sağlanmadığı Schoenfed artıkları ile yaşam sürelerinin rankının korelasyon testi kullanılarak incelenebilir. Bu teste göre, orantılı hazard varsayımının sağlanması için 
korelasyonun sıfira yakın olması beklenilir (7). Çalışmamızda "orantılı hazard varsayımı sağlanmaktadır" şeklinde kurulan yokluk hipotezi reddedilmiştir. O halde analizimizde Cox regresyon modelini kullanmak mümkün değildir. Literatürde orantılı hazard varsayımı sağlanmıyorsa yaşam verilerinin modellenebilmesi için yarı parametrik modellerden orantısızlığa neden olan değişken kullanılarak tabakalandırma yapılarak tabakalandırılmış Cox regresyon modeli kullanılabileceği gibi, parametrik regresyon modelleri ya da bireyler arasındaki heterojenliği ortaya çıkarmak için parametrik regresyon modellerinden zayıflık modeli kullanılabilir (8). Zayıflık modeli hastalar arasındaki heterojenliği açıklamak için ölçülemeyen rastgele etkiyi hazard fonksiyonuna dahil eder (9). Zayıflık modeli hazard fonksiyonu üzerinde gözlenemeyen etkiyi modellemek için kullanılır $(10,11)$. Ayrıca araştırmamızda sağkalım süresi analizi Kaplan-Meier yöntemi ile hesaplandi.

\section{Bulgular}

Cox regresyon modelinin orantil hazard varsayımını sağlayıp sağlamadığı Schoenfed artıkları ile yaşam sürelerinin rankının korelasyon testi ve grafik kullanılarak incelendi (Şekil 1). Tümör boyutu değişkeni için orantı1ı hazard varsayımının sağlanmadığı görüldü $(\mathrm{p}=0.0002)$.

Varsayım sağlanmadığında literatürde tanımlanan farklı sağkalım modelleri vardır. Çalışmamızda bu modellerden zayıflık modeli kullanıldı. Yaşam analizinde hastalar arasındaki gözlenemeyen ölçülemeyen heterojenliği ortaya çıkarmak ve modele dahil etmek için zayıflık modeli kullanılmaktadır. Bu çalışmada meme kanseri hastaları arasındaki gözlenemeyen etkiyi açıklamak için zayıflık modeli ile analiz yapıldı. Öncelikle zayıflık modelinde hangi parametrik regresyon modelinin kullanılacağına karar vermek için meme kanseri verileri parametrik regresyon modellerinden Üstel, Weibull, Log-lojistik, Log-normal, Gompertz regresyon modelleri kullanıld. Modellerin anlamlılığını test etmek için olabilirlik oran test istatistiği kullanıldı ve tüm modellerin istatistiki olarak anlamlı olduğu bulundu $(\mathrm{p}<0.05)$. Model seçiminde ise AIC ve BIC kriter değerlerine bak1larak karar verildi.

Tablo 2'de yer alan sonuçlara göre en uygun modelin en küçük AIC ve BIC değerlerine göre Log-Normal regresyon olduğuna karar verildi. Uygun modelin LogNormal dağılım olduğuna karar verildikten sonra Gamma zayıflık terimi içeren LogNormal modeli ile analize devam edildi ve analizin sonuçları tablo 3 'te verildi.

Gamma zayıflık terimi ile kurulan modelin anlamlılığı olabilirlik oran testi ile değerlendirildiğinde $\mathrm{p}<0.001$ bulunduğundan zayıflık teriminin model üzerinde etkiliği olduğu sonucuna varıldı. Bu sonuç bize yaşam süresinde etkili bir gizli faktör ya da faktörlerin olduğunu ifade eder. Diğer bir ifade ile zayıflık terimi heterojenliğin ölçüsü olup karekökünün üstel ifadesi heterojenliğin etkisini göstermektedir. $\exp (\sqrt{1.28})=3.1$ bu değer herhangi bir meme kanseri hastasının belirlenen bir zamanda, tüm hastalara ait riskten yaklaşık 3 kat daha fazla ya da yaklaşı 3 kat daha az risk taşıyabileceğini ifade eder. Tablo 3 'teki $\mathrm{p}$ değerleri incelendiğinde tümör boyutu, lenf nodu sayıs1, hormon reseptörleri ve cerrahi işlem ile kemoterapi başlama tarihi arasında geçen süre faktörlerinin yaşam süresini etkileyen önemli risk faktörleri olduğu \%95 güven seviyesinde bulundu. Tümör boyutunun başarısızlığı etkileyen önemli bir faktör olduğu görülmektedir $(\mathrm{p}<0.001)$. Lenf nodu sayısının çok olması durumu başarısızlığı etkileyen önemli bir faktördür $(p<0.001)$. Cerrahi işlem ile kemoterapi başlama tarihi arasındaki süre başarısızlığı etkileyen bir faktördür $(p=0.002)$. Hormon reseptörünün negatifliği başarısızlığ etkileyen bir faktör olarak bulundu $(\mathrm{p}=0.02)$. Oysaki; yaş değişkeni $(\mathrm{p}=0.15)$, tümör olan bölgenin vücudun sağ ya da sol tarafında olması $(\mathrm{p}=0.09)$, tümör çapı $(\mathrm{p}=0.48)$ gibi faktörlerin yaşam süresi üzerinde etkisi istatistiki olarak anlamlı bulunmamıştır. Tümör boyutu büyük olan hastaların yaşam süresi tümör boyutu küçük olan hastalara göre yaklaşık 3.7 (exp $(1.33)=3.7)$ kat daha kisadır. Lenf nodu sayıs1 fazla olan hastaların yaşam süresi lenf nodu sayıs1 az olan hastalara göre yaklaşık 4.3 (exp $(1.47)=4.3)$ kat daha kısadır. Hormon reseptörü negatif olan hastaların pozitif olan hastalara göre yaşam süresi yaklaşık $3.1(\exp (0.76)=3.1)$ kat daha kısadır. Çalışmamız, cerrahi işlem ile kemoterapi başlama tarihi arasındaki süre uzadıkça hastanın daha riskli olduğunu ve bu süreyi geciktiren hastaların bu süreyi geciktirmeyen hastalara göre yaklaşı 3.06 $(\exp (1.12)=3.06)$ kat daha fazla risk taşıdığını göstermektedir. 
Analize alınan 181 meme kanserli hastanın ortanca genel sağkalımı 74 ay (\%95 güven aralığ1; 61.88-86.78) olarak bulundu. Hastaların genelinde elde edilen Kaplan-Meier sağkalım eğrisi şekil 2' de gösterildi.

\section{Tartışma ve Sonuç}

Chang ve ark, meme kanseri araştırmasında Bcl-2 ekspresyonu ve hormon reseptörü faktörlerinin sağkalımı etkilediğini ispatlamışlardır (12). Gioia ve ark, ca 15-3'ü araştırdıkları makalede tümör çapı, metastatik lenf nodu (LN) sayısı, negatif hormon reseptörü durumu ve HER-2/NEU pozitifliği gibi kötü prognostik faktörler ile ilişkili olduğunu bildirmişlerdir (13). Robertson ve ark, meme kanserli hastalarda yapılan çalışmada primer tümörün sağkalımı belirleyen önemli bir faktör olduğunu bulmuşlardır (14). Sezgin ve ark, metastatik meme kanserli hastalarda yaptıkları çalışmada sağkalımı etkileyen faktörlerin hormon reseptör negatifliği, düşük performans durumu ve metastaz varlığ 1 olduğunu bildirmişlerdir (15). Bizim araştırmamızda ise tümör boyutu, metastatik lenf nodu sayıs1, hormon reseptörleri ve cerrahi işlem ile kemoterapi başlama tarihi arasında geçen süre faktörlerinin yaşam süresini etkileyen önemli risk faktörleri olduğu bulundu. Faradmal ve ark, yaptıkları çalışmada meme kanseri hastalarında zayıflık modeli ile Cox regresyon modeli karşılaştırmışlar ve zayıflık modelinin heterojenliği ortaya çıkardığını ifade etmişlerdir (16). Bizim araştırmamız ise Cox regresyon modeli varsayımı sağlanamadığı için analiz zayıflık modeli ile yapıldı. Bu araştırmada Gamma zayıflık terimi içeren Log-Normal modeli ile yapilan analiz sonucunda meme kanseri hastalarının yaşam süresini etkileyen tümör boyutu, lenf nodu büyüklüğü, hormon reseptörünün negatifliği ve cerrahi müdahale ile kemoterapi başlama tarihi arası geçen zamanın uzatılması gibi faktörlerin yanı sıra çevresel ya da genetik gizli faktörlerin olabileceği söylenebilir. Bu gizli faktör ya da faktörlerin herhangi bir meme kanseri hastasında 3 kat daha fazla risk taşıdığını ifade edebiliriz.

Bundan sonraki çalışmalarımızda tekrarlayan metastaz hastalarının başarısızlıklarını modellemeyi düşünmekteyiz.

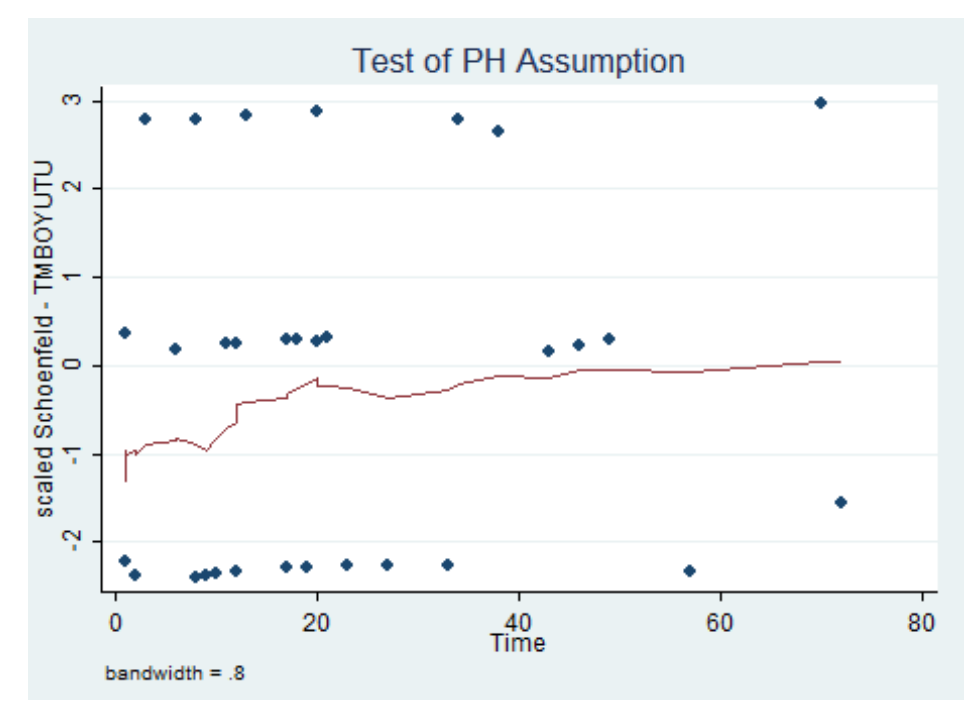

Şekil 1: Tümör boyutu değişkeninin Schoenfeld grafiği 
Tablo 1: Hastaların demogratif özellikleri ve prognostik faktörleri

\begin{tabular}{|c|c|c|c|c|}
\hline Değişkenler & $\begin{array}{l}\text { Değişken düzeyleri } \\
\text { (Ortalama, } \pm \text { Standart } \\
\text { Hata) }\end{array}$ & $\mathbf{N}(\%)$ & $\begin{array}{c}\text { Durdurulmuş } \\
\text { Olay Sayısı (\%) }\end{array}$ & $\begin{array}{c}\text { Başarısız Olay } \\
\text { Sayısı (\%) }\end{array}$ \\
\hline Hastanın Yaşı & $48,79 \pm 0,88$ & & & \\
\hline \multirow{2}{*}{ Menopoz Durumu } & Premenopozal & $103(56.90)$ & $75(72.80)$ & $28(27.20)$ \\
\hline & Postmenopozal & $78(43.10)$ & $58(74.40)$ & $20(25.60)$ \\
\hline \multirow{2}{*}{$\begin{array}{c}\text { Tümör } \\
\text { Lokalizasyonu }\end{array}$} & Sol MRM & $96(53.00)$ & $66(68.80)$ & $30(31.30)$ \\
\hline & Să̆ MKC & $85(47.00)$ & $67(78.80)$ & $18(21.20)$ \\
\hline \multirow{3}{*}{ Tümör Boyutu } & $<2 \mathrm{~cm}$ & $53(29.30)$ & $28(52.80)$ & $25(47.20)$ \\
\hline & $2-5 \mathrm{~cm}$ & $95(52.50)$ & $79(83.20)$ & $16(16.80)$ \\
\hline & $>5 \mathrm{~cm}$ & $33(18.20)$ & $26(78.80)$ & $7(21.20)$ \\
\hline \multirow{4}{*}{$\begin{array}{c}\text { Metastatik Lenf } \\
\text { Nodu Sayısı }\end{array}$} & $\mathbf{0}$ & $60(33.10)$ & $39(65.00)$ & $21(35.00)$ \\
\hline & $1-3$ & $35(19.30)$ & $30(85.70)$ & $5(14.30)$ \\
\hline & $4-9$ & $62(34.30)$ & $46(74.20)$ & $16(25.80)$ \\
\hline & $\geq 10$ & $24(13.30)$ & $18(75.00)$ & $6(25.00)$ \\
\hline \multirow{2}{*}{ HR } & Negatif & $51(28.20)$ & $38(74.50)$ & $13(25.50)$ \\
\hline & Pozitif & $130(71.80)$ & $95(73.10)$ & $35(26.90)$ \\
\hline \multirow{2}{*}{ C-ERB B2 } & Negatif & $110(60.80)$ & $84(76.40)$ & $26(23.60)$ \\
\hline & Pozitif & $71(39.20)$ & $49(69.00)$ & $22(31.00)$ \\
\hline
\end{tabular}

HR: Hormon Reseptörü

Tablo 2: Parametrik regresyon modelleri için AIC ve BIC değerleri

\begin{tabular}{|l|l|l|l|l|l|}
\hline Kriter & Üstel & Weibull & Log-lojistik & Log-Normal & Gompertz \\
\hline AIC & 344.10 & 334.22 & 332.61 & $\mathbf{3 2 8 . 8 1}$ & 339.18 \\
\hline BIC & 350.50 & 343.82 & 342.20 & $\mathbf{3 3 8 . 4 1}$ & 348.77 \\
\hline
\end{tabular}

AIC: Akaike bilgi kriteri BIC: Bayesci bilgi kriteri 
Tablo 3: Gamma zayıflık terimi içeren Log-Normal model ile analiz

\begin{tabular}{|c|c|c|c|c|c|}
\hline \multirow{2}{*}{ Değişkenler } & \multirow{2}{*}{$\boldsymbol{\beta}$} & \multirow{2}{*}{$\begin{array}{c}\text { Standart } \\
\text { Hata }\end{array}$} & \multirow{2}{*}{$\mathbf{p}$} & \multicolumn{2}{|c|}{ Güven Aralığı } \\
\hline & & & & Alt & Üst \\
\hline Yaş & 0.02 & 0.01 & 0.15 & -0.007 & 0.04 \\
\hline Tümör Boyutu & 1.33 & 0.33 & $<0.001$ & 0.67 & 1.98 \\
\hline Metastatik Lenf Nodu & 1.47 & 0.38 & $<0.001$ & 0.72 & 2.22 \\
\hline Tümör Olan Bölge & 0.52 & 0.31 & 0.09 & -0.08 & 1.13 \\
\hline Tümör Çapı & -0.28 & 0.40 & 0.48 & -1.06 & 0.50 \\
\hline HR & 0.76 & 0.34 & 0.02 & 0.09 & 1.43 \\
\hline CERBB2 & -0.38 & 0.49 & 0.43 & -1.35 & 0.58 \\
\hline Metastaz Bölgesi & 0.16 & 0.63 & 0.79 & -1.08 & 1.41 \\
\hline $\begin{array}{l}\text { Cerrahi ile Kemoterapi } \\
\text { Arasında Geçen Süre }\end{array}$ & 1.12 & 0.36 & 0.002 & 0.41 & 1.83 \\
\hline Zayıflık Terimi ( $(\theta)$ & 1.28 & & $<0.001$ & & \\
\hline
\end{tabular}

HR: Hormon Reseptörü

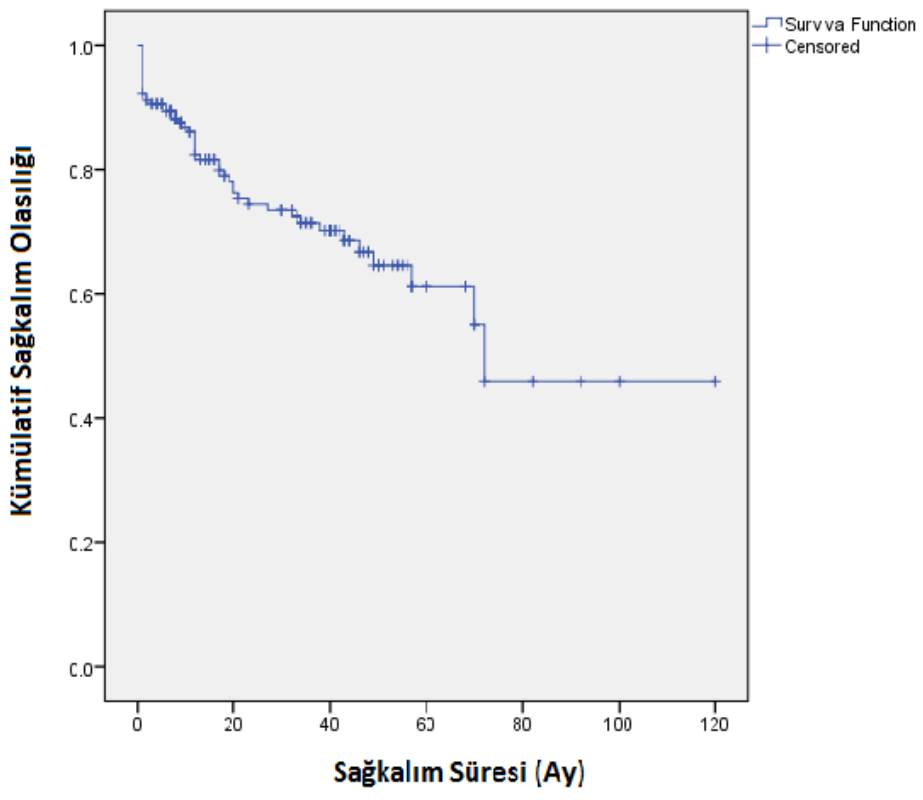

Şekil 2: Meme kanserli tüm olguların Kaplan Meier sağkalım eğrisi 


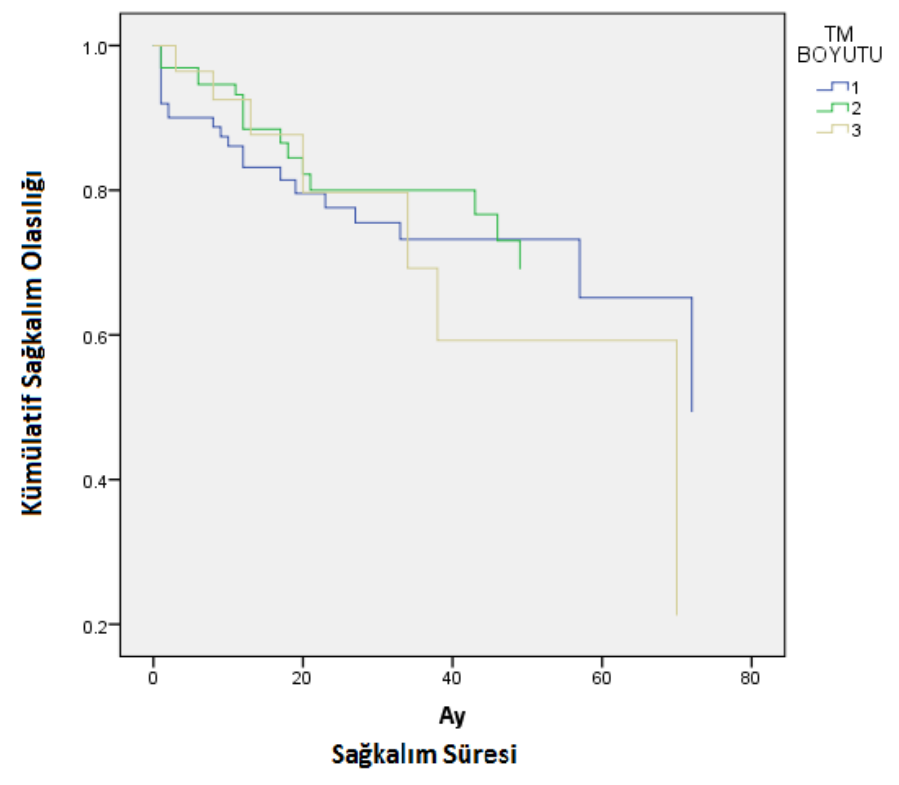

Şekil 3: Tümör boyutu (0-2), (2-5), (5 ve daha büyük) olan üç grubun sağkalım eğrileri

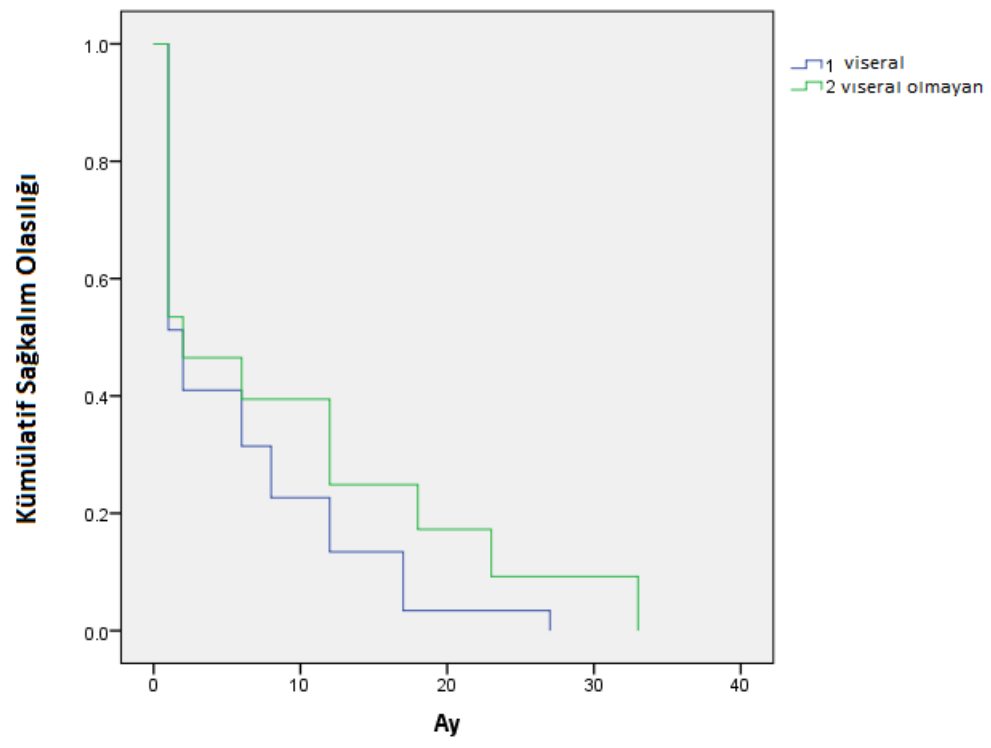

Şekil 4: Metastazı visseral ve visseral olmayan iki grubun sağkalım eğrileri 


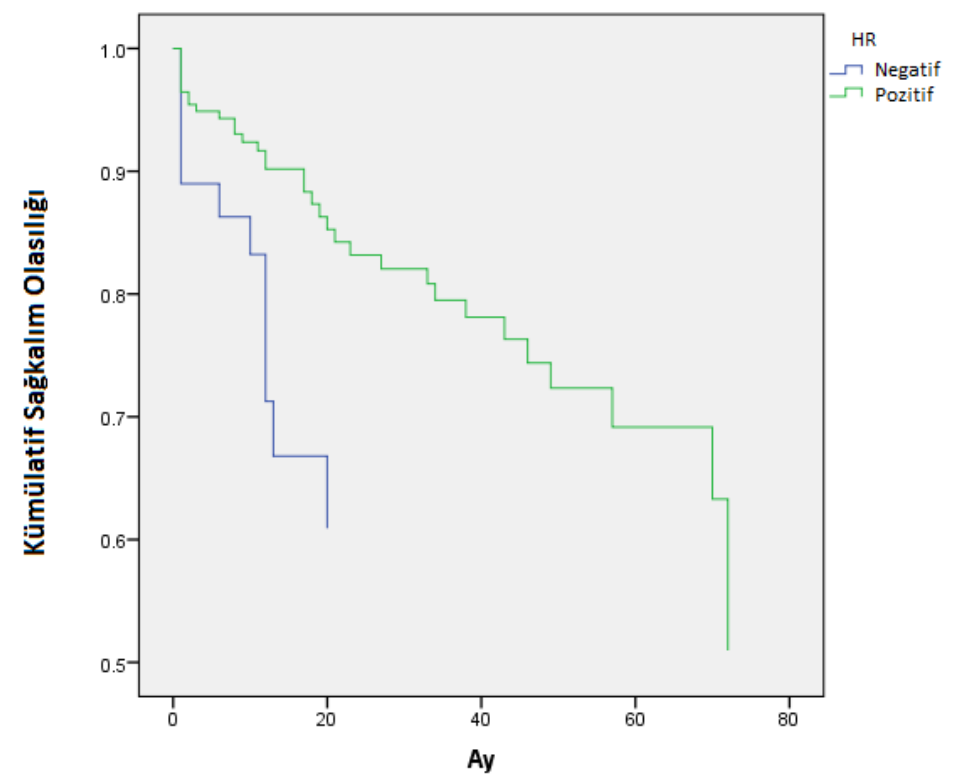

Şekil 5: HR pozitif ve negatif olan iki grubun karşılaştırılması

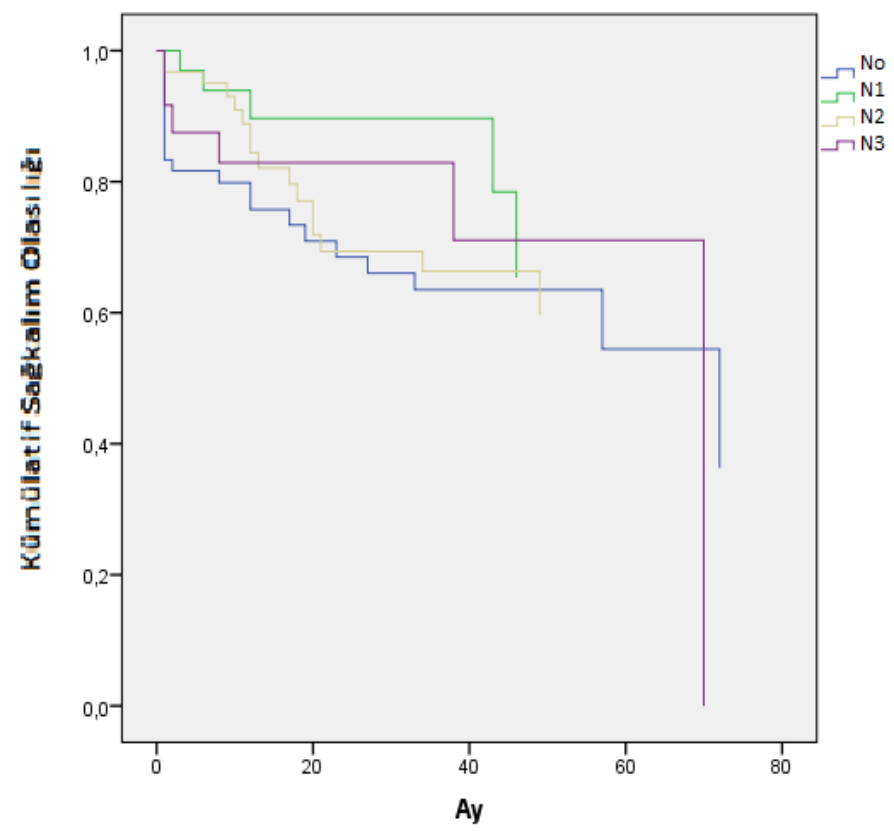

Şekil 6: Metastatik lenf nodu sayıs1 N0: 0, N1: 1ve 3 aras1, N2: 4 ve 9 aras1, N3: 10'dan büyük

\section{Referanslar}

1. Jemal A, Bray F, Center MM, Ferlay J, Ward E, Forman D. Global Cancer statistics. CA Cancer J Clin. 2011;61:69-90.

2. Statistics with Stata (updated for version 9) / Lawrence Hamilton; Thomson Books/Cole; 2006.
3. Hammond ME, Hayes DF, Dowsett M, et al. American Society of Clinical Oncology/ College of American Pathologists guideline recommendations for immunohistochemical testing of estrogen and progesterone receptors in breast cancer. J Clin Oncol. 2010; 28:27842795.

4. Paik S, Bryant J, Tan-Chiu E et al. Real world performance of HER 2 testing- national

Adress for correspondence: Uzm. Dr. İsa Dede, Antakya Devlet Hastanesi, Tıbbi Onkoloji Kliniği, Samsun - Türkiye 
surgical adjuvant breast and bowel project experince. J Natl Cancer Inst 2002; 94 (11):855857.

5. Eliyatkın N, Zengel B, Aktaş S. Meme kanserinde HER-2/NEU (C-ERB-B2) durumunun önemi: Hangi yöntemle değerlendirmek daha uygun? J Breats Health 2013;9:175-81.

6. Persson, I. Essays on the Assumption of Proportional Hazards in Cox Regression. Uu.diva-

portal.org/smash/get/diva2:161225/Fultext01. 2002;11-24

7. Song, H.H. and Lee, S. Comparison of goodness of fit tests for the Cox proportional hazards model. Communications in StatisticsSimulation and Computation. 2000;29(1):187206.

8. Hanagal DD. Modelling survival data using frailty model (1nd ed). London; Chapman \& Hall/CRC; 2011:71-96.

9. Karasoy D, Tutkun NA. Yaşam Çözümlemesi (Birinci Basım). Nobel Akademik Yayıncılı;; 2016:53-69.

10. Perperoglou A, Keramopoullos A, Van Houwelingen HC. Approaches in modelling long-term survival: an application to breast cancer. Stat Med. 2007;26(13):2666-2685.
11. Kleinbaum DG, Klein M. Survival analysis: a self-learning text (2nd ed). New York; Springer; 2005:257-327.

12. Gioia DD, Dresse M, Mayr D, Nagel D, Heinemann V, Stieber P. Serum HER2 in combination with CA 15-3 as a parameter for prognosis in patients with early breast cancer. Clin Chim Acta.2015;440:16-22.

13. Chang J, Clark GM, Allred DC, Mohsin S, Chamness G, Elledge R M. Survival of patients with metastatic breast carcinoma: İmportance of prognostic markers of the primary tumor. Cancer 2003; 97(3):547-53

14. Robertson JF, Dixon AR, Nicholson RI, Ellis IO, Eltson CW, Blamey RW. Confirmation of a prognostic index for patients with metastatic breast cancer treated by endocrine therapy. Breast Cancer Res Treat 1992;22(3):221-7.

15. Sezgin C, Zekioğlu O, Gökmen E. Türk Onkoloji Dergisi, İlk tanıda metastatik meme kanseri ile başvuran hastaların sağkalımını etkileyen prognostik faktörler. 2006;21(1):2025

16. J. Faradmal, A. Talebi, A. Rezaianzadeh, and H. Mahjub. Survival analysis of breast cancer patients using cox and frailty models, Journal of Research in Health Sciences, 2012;12(2): 127130. 